\title{
The Concise Synthesis of Spiro-Cyclopropane Compounds via the Dearomatization of Indole Derivatives
}

\author{
Jing Luo, ${ }^{\dagger}$ Bo Wu, Mu-Wang Chen, ${ }^{\ddagger}$ Guo-Fang Jiang, ${ }^{*}{ }^{\dagger}$ and Yong-Gui Zhou* ${ }^{*}$ \\ ${ }^{\dagger}$ State Key Laboratory of Chemo/Biosensing and Chemometrics, College of Chemistry and Chemical Engineering, Hunan University, \\ Changsha 410082, China \\ ${ }^{\ddagger}$ State Key Laboratory of Catalysis, Dalian Institute of Chemical Physics, Chinese Academy of Sciences, 457 Zhongshan Road, Dalian \\ 116023, China
}

\section{Supporting Information}

ABSTRACT: A concise synthesis of spiro-cyclopropane compounds from indole derivatives and sulfur ylides has been developed via a dearomatization strategy. Moreover, the spiro-cyclopropane compounds could be conveniently transformed to rearomatized indole derivatives in the presence of acids.
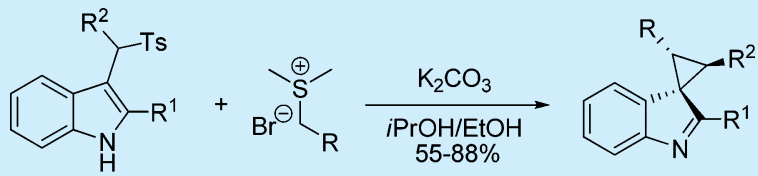

$\mathrm{D}$ earomatization reactions are important transformations of aromatic compounds because they directly lead to a variety of ring systems. ${ }^{1}$ Additionally, they are highly efficient for constructing quaternary carbon centers ${ }^{2}$ and used as the key steps in the total synthesis of many natural products. ${ }^{3}$ In this regard, dearomatization reactions of indoles, ${ }^{4}$ pyridines, ${ }^{5}$ phenols, ${ }^{6}$ pyrroles, ${ }^{7}$ etc., have been developed. Among them, compounds with an indole skeleton have attracted enormous attention because of the important biological activities of their derivatives. ${ }^{8}$ Dearomatization reaction of indoles has been extensively studied over the past decades, with particular focuses on alkylative dearomatization ${ }^{9}$ and oxidative dearomatization. ${ }^{10}$ In addition, the Diels-Alder pathway with various dienophiles $^{11}$ and organocatalyzed Michael/Mannich cyclization cascade reactions were also demonstrated in dearomatization reactions of indoles. ${ }^{12}$ Besides, several transition-metalcatalyzed dearomatization reactions of indoles were also documented. ${ }^{13}$ Although great progress has been made in the dearomatization reaction of indoles, most of the methods required harsh conditions and designed catalysts that are currently commercially unavailable. Thus, to develop a facile and efficient method for a dearomatization reaction of indole derivatives from readily available starting materials would be of considerable significance in organic chemistry.

Spiro-cyclopropane structure motifs are ubiquitous and prevalent in various anticancer agents and pharmaceuticals. ${ }^{14}$ In addition, they also serve as valuable synthetic intermediates for a wide range of organic compounds. ${ }^{15}$ Therefore, the construction of spiro-cyclopropane skeletons has achieved extensive attention, and a plethora of efficient methods have been developed for the synthesis of these important structures, including from alkenes by Simmons-Smith and related reactions or with ylides, transition-metal-catalyzed carbene transfer, Michael-initiated ring closure (MIRC), and organocatalytic cyclopropanation, which have been described in the literature. $^{16,17}$
The use of an arylsulfonyl group as an auxiliary group is still a prominent synthetic strategy in organic synthesis. ${ }^{18}$ Recently, the utilization of the arylsulfonyl group in connection with indole has attracted intriguing interests. The sulfonyl moiety at the benzylic position of 3-substituted indoles acts as a good leaving group, which enables the generation of vinylogous imines intermediates under basic conditions. The generating vinylogous imines intermediates are equal to $\alpha, \beta$-unsaturated imines, which are able to react with numerous nucleophiles. ${ }^{19}$ Considering that sulfur ylides act as a nucleophile under the basic condition, ${ }^{20}$ the vinylogous imine intermediates can be generated from arenesulfonylindole under the mild basic conditions. We envisioned that ylides could react with the vinylogous imine intermediates to furnish the spiro-cyclopropane compounds (Scheme 1). Herein, we report an efficient

Scheme 1. Synthesis of Spiro-Cyclopropane Compounds via the Dearomatization of Indoles

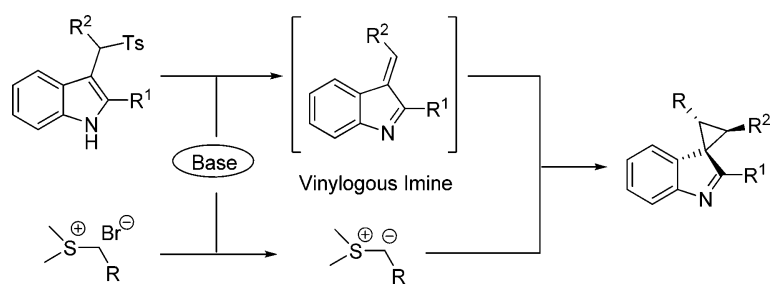

dearomatization reaction of indole derivatives in which arylsulfonyl group acts as a leaving group with sulfonium salts under mild conditions to synthesize spiro-cyclopropane compounds.

Initially, our investigation was launched with 2-methylsubstituted arenesulfonylindole 1a (1.0 equiv), sulfonium salt 2a (1.5 equiv), $\mathrm{K}_{2} \mathrm{CO}_{3}$ (3.0 equiv) as the base in $\mathrm{CH}_{2} \mathrm{Cl}_{2}$

Received: January 22, 2014

Published: May 6, 2014 
(Table 1). Delightfully, the spiro-cyclopropane products 3a and $3 a^{\prime}$ were obtained with $71 \%$ yield and a ratio of $3: 1$. Next, a

Table 1. Optimization for the Reaction of 2Methylarenesulfonylindole 1a with Sulfonium Salt $2 \mathrm{a}^{a}$

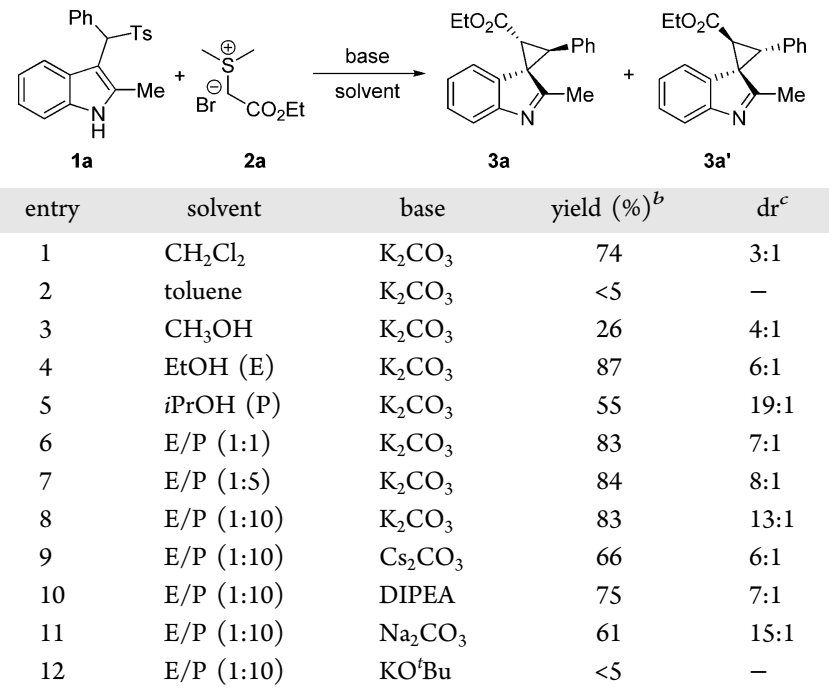

${ }^{a}$ Condition: $0.25 \mathrm{mmol} \mathrm{1a}, 0.375 \mathrm{mmol} 2 \mathrm{a}, 0.75 \mathrm{mmol}$ base, $3.3 \mathrm{~mL}$ of solvent, room temperature, $12 \mathrm{~h} .{ }^{b}$ Isolated yields of the mixture of $3 \mathrm{a}$ and $3 a^{\prime}$. ' $A$ All of the $\mathrm{dr}\left(3 \mathrm{a} / 3 \mathbf{a}^{\prime}\right)$ were determined by ${ }^{1} \mathrm{H}$ NMR spectroscopy. E/P: EtOH/iPrOH.

series of solvents were examined, and to our delight, high yield was obtained from EtOH (87\%, Table 1, entry 4), and $i \mathrm{PrOH}$ gave the excellent 19:1 of diastereoselectivity (Table 1, entry 5). Thus, the next screening was focused on the mixed solvents. When the ratio of $i \mathrm{PrOH} / \mathrm{EtOH}$ was 10:1, the yield could be retained, and the diastereoselectivity could be raised up to 13:1 (Table 1, entry 8); several other bases were also examined, and moderate yields and diastereoselectivities were obtained (Table 1, entries 9-11). So, the optimal conditions were established, $\mathrm{K}_{2} \mathrm{CO}_{3}$ as the base and $i \mathrm{PrOH} / \mathrm{EtOH}(10: 1)$ as the solvent.

With the optimized conditions in hand, we explored the reaction scope using a variety of 2-substituted arenesulfonylindoles $\mathbf{1}$ and sulfonium salts $\mathbf{2}$ as listed in Table 2. A range of sulfonium salts were examined, and medium to good yields and excellent diastereoselectivitives were achieved (55-78\% yields, $\mathrm{dr}=13: 1$ to $>20: 1$, Table 2, entries 2-5). Especially, when $\mathrm{R}$ was aryl carbonyl, up to $>20: 1$ diastereoselectivity were obtained. The steric and electronic property of the aryl substituents had little effect on the yield and diastereoselectivity for substituents $\mathrm{R}^{2}$ (Table 2, entries 7-13); all of them could get satisfactory yields and diastereoselectivity. The electronic nature of the indole core had little influence on the outcome of the reactions; when the sulfonylindoles with fluorine or methyl as substituent at the 5-position of the indole ring, both gave excellent yields and satisfactory diastereoselectivities (Table 2, entries 14-15). It is worthy of note that when the 2-position of the indole ring was phenyl, the diastereoselectivity was reversed (Table 2, entry 16), which may ascribe to the change of geometry of $\mathrm{C}=\mathrm{C}$ bond and relative stability of vinylogous imine intermediate due to steric hindrance of phenyl group. To our delight, the 2-position unsubstituted sulfonyl indoles were also suitable reaction partners using ethanol as solvent and provided the desired products in good yields and excellent diastereoselectivities (Table 2 , entries $17-20)^{21}$
Table 2. Scope for the Reaction of Arenesulfonylindoles 1 with Sulfonium Salts $2^{a}$

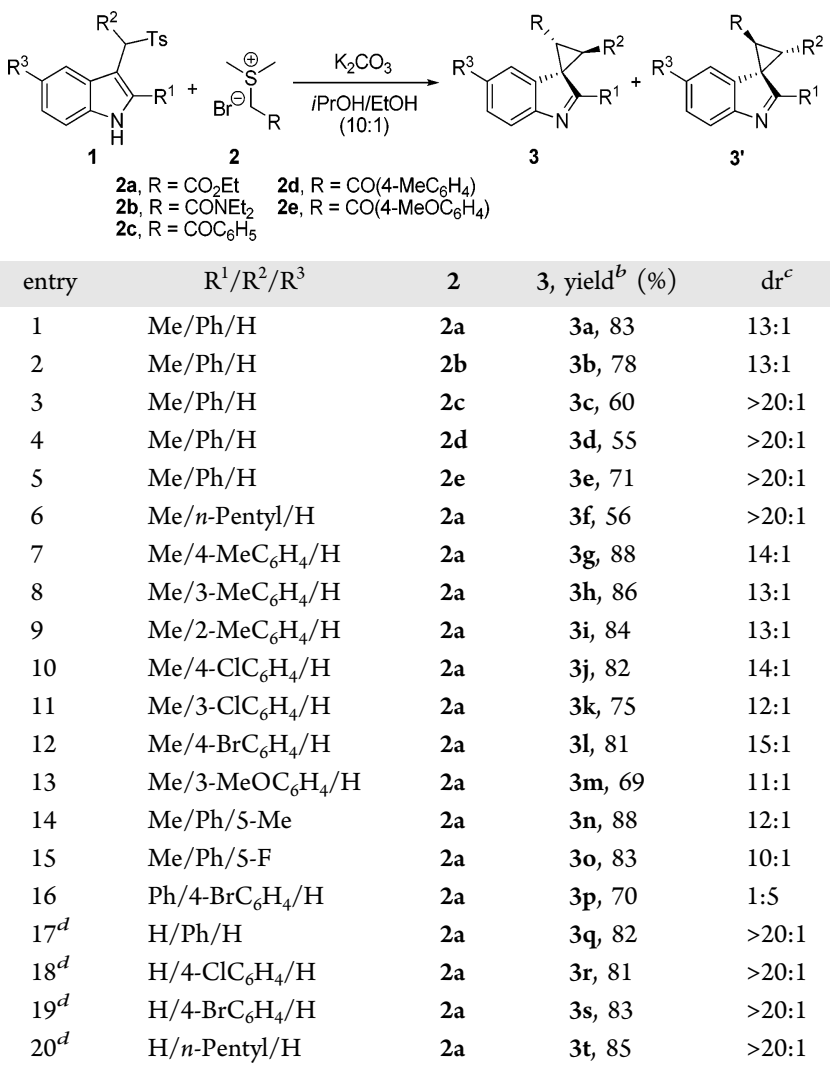

${ }^{a}$ Condition: $0.25 \mathrm{mmol} \mathrm{1,} 0.375 \mathrm{mmol} \mathrm{2,} 0.75 \mathrm{mmol} \mathrm{K}_{2} \mathrm{CO}_{3}, 3.0 \mathrm{~mL}$ of $\mathrm{PrOH}, 0.3 \mathrm{~mL}$ of EtOH, room temperature, $12 \mathrm{~h}$. ${ }^{b}$ Isolated yields of the mixture of 3 and $3^{\prime}$. ${ }^{c}$ All of the $\mathrm{dr}\left(3 / 3^{\prime}\right)$ were determined by ${ }^{1} \mathrm{H}$ NMR spectroscopy. ${ }^{d} 3.3 \mathrm{~mL}$ of EtOH was used.

The structure and stereochemistry of spiro-cyclopropanes 3a (Figure 1), $3 p$, and $3 \mathbf{p}^{\prime}$ were verified by the combination of

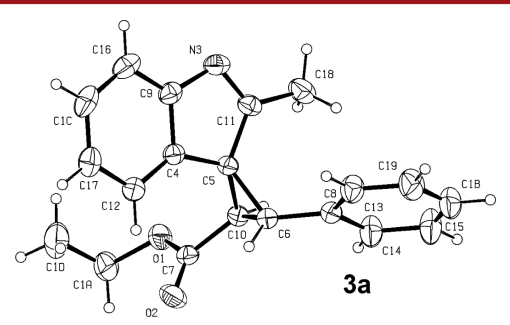

Figure 1. X-ray crystal structure of compound 3a.

NMR, HRMS spectroscopy, and single-crystal X-ray diffraction anaysis (for X-ray crystal structure of $3 p$ and $3 p^{\prime}$, see the Supporting Information). ${ }^{22}$

Furthermore, a preliminary study on the enantioselective version of this dearomatization reaction was also tried. Using the known chiral sulfonium salts ${ }^{23}$ originally developed by Aggarwal, only moderate enantioselectivity $64 \%$ ee and low yield (29\%) were obtained (Scheme 2). These promising results demonstrated the potential for synthesis of the chiral spiro-cycopropane derivatives, although more efficient catalytic systems need to be developed.

It is noted that the model substrates $1 \mathbf{a}$ and $\mathbf{2 a}$ could also be carried out at a gram scale. As illustrated in Scheme 3, the target 
Scheme 2. Synthesis of Chiral Spiro-Cyclopropane with the Chiral Sulfonium Salt

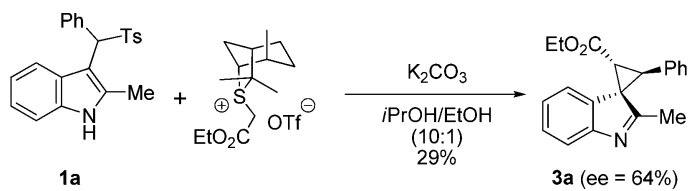

products $3 \mathbf{a}$ and $3 \mathbf{a}^{\prime}$ could be obtained in $82 \%$ yield and the diastereoselectivity could be kept with 13:1.

Scheme 3. Scale-up of Model Substrates

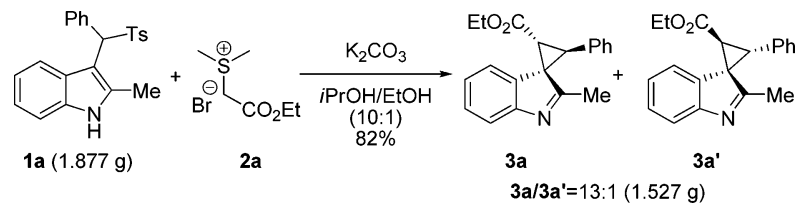

In order to explore the application of our methodology, we tried to transform them to rearomatized 2,3-disubstituted indole derivatives (Scheme 4). Pleasingly, when trifluoroacetic

Scheme 4. Selective Transformations of $3 a$ to Rearomatized Indole Derivatives

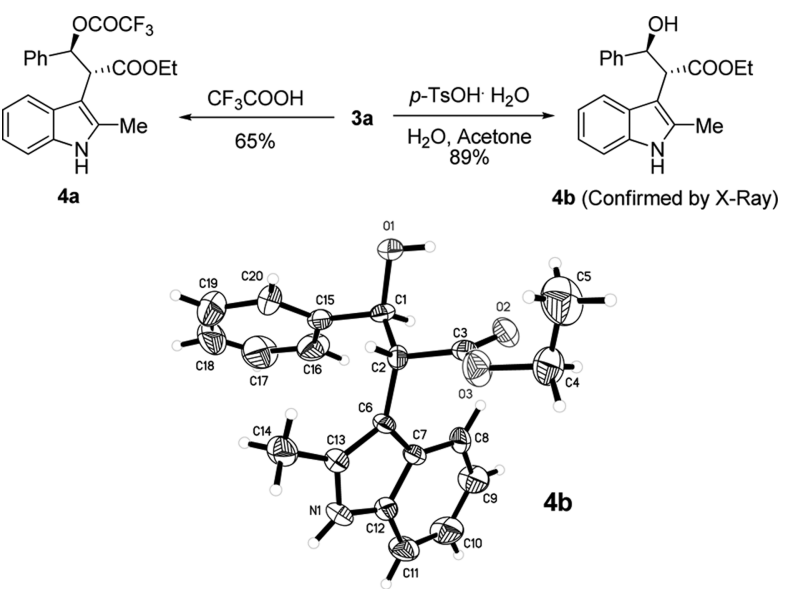

acid was added, the expected rearomatized product $\mathbf{4 a}$ was obtained in $65 \%$ yield with excellent diastereoselectivity; trifluoroacetic acid served as both acid and nucleophile in this reaction. When water was chosen as nucleophile, the product hydroxyl ester $\mathbf{4 b}$ could also be obtained with $89 \%$ yield with excellent diastereoselectivity. The single-crystal of $4 b^{24}$ was successfully obtained and confirmed the relative configuration (see the Supporting Information).

In conclusion, we have developed a concise and efficient dearomatization method for the rapid and facile synthesis of spiro-cyclopropane compounds via the vinylogous imine intermediates generated from readily available arenesulfonylindoles and sulfonium salts under mild basic conditions. This methodology provides a succinct access to substituted spirocyclopropane derivatives. Moreover, the spiro-cyclopropanes could be conveniently transformed to rearomatized indole derivatives with excellent yields in the presence of acids. Our ongoing studies are focused on an asymmetric version of this reaction.

\section{ASSOCIATED CONTENT}

\section{Supporting Information}

Experimental procedures, characterization data, X-ray structures, data for the determination of enantiomeric excess, and NMR spectra. This material is available free of charge via the Internet at http://pubs.acs.org.

\section{AUTHOR INFORMATION}

\section{Corresponding Authors}

*E-mail: gfjiang@hnu.edu.cn.

*E-mail: ygzhou@dicp.ac.cn.

Notes

The authors declare no competing financial interest.

\section{ACKNOWLEDGMENTS}

We are grateful for the financial support from the National Natural Science Foundation of China (J1210040) and the National Basic Research Program of China (2010CB833300).

\section{REFERENCES}

(1) (a) Newhouse, T.; Baran, P. S.; Hoffmann, R. W. Chem. Soc. Rev. 2009, 38, 3010. (b) Ortiz, F. L.; Iglesias, M. J.; Fernández, I.; Sánchez, C. M. A.; Gómez, G. R. Chem. Rev. 2007, 107, 1580.

(2) (a) Liu, Q.; Rovis, T. J. Am. Chem. Soc. 2006, 128, 2552. (b) Gong, J.; Lin, G.; Li, C.-C.; Yang, Z. Org. Lett. 2009, 11, 4770.

(c) Jia, M.-Q.; You, S.-L. Synlett 2013, 1201.

(3) For reviews, see: (a) (a) Nicolaou, K. C.; Chen, J. S. Chem. Soc. Rev. 2009, 38, 2993. (b) Rassu, G.; Zanardi, F.; Battistini, L.; Casiraghi, G. Chem. Soc. Rev. 2000, 29, 109. For selected examples: (a) Cha, J. Y.; Huang, Y.; Pettus, T. R. R. Angew. Chem., Int. Ed. 2009, 48, 9519.

(b) Zuo, Z.; Xie, W.; Ma, D. J. Am. Chem. Soc. 2010, 132, 13226.

(c) Zuo, Z.; Ma, D. Angew. Chem., Int. Ed. 2011, 50, 12008.

(d) Horning, B. D.; MacMillan, D. W. C. J. Am. Chem. Soc. 2013, 135, 6442.

(4) For recent reviews on dearomatization of indoles, see: (a) Zhuo, C.-X.; Zhang, W.; You, S.-L. Angew. Chem., Int. Ed. 2012, 51, 12662. (b) Roche, S. P.; Porco, J. A. Angew. Chem., Int. Ed. 2011, 50, 4068. (c) Chen, Q.-A.; Ye, Z.-S.; Duan, Y.; Zhou, Y.-G. Chem. Soc. Rev. 2013, $42,497$.

(5) For dearomatization of pyridines reviews, see: (a) Lavilla, R. J. Chem. Soc., Perkin Trans. 1 2002, 1141. (b) Comin, D. L. J. Heterocycl. Chem. 1999, 36, 1491. For selected examples see: (a) Wang, S.-G.; Zhang, W.; You, S.-L. Org. Lett. 2013, 15, 1488. (b) Dai, C.; Liang, B.; Stephenson, C. R. J. Beilstein. J. Org. Chem. 2012, 8, 986. (c) Mousseau, J. J.; Fortier, A.; Charette, A. B. Org. Lett. 2010, 12, 516. (d) Sun, Z.; Yu, S.; Ding, Z.; Ma, D. J. Am. Chem. Soc. 2007, 129, 9300. (e) Wang, S.-G.; You, S.-L. Angew. Chem., Int. Ed. 2014, 53, 2194.

(6) For dearomatization of phenols reviews, see: (a) Ding, Q.; Ye, Y.; Fan, R. Synthesis 2013, 1. (b) Pouységu, L.; Deffieux, D.; Quideau, S. Tetrahedron 2010, 66, 2235. (c) Quideau, S.; Pouységu, L.; Deffieux, D. Synlett 2008, 467. For selected examples, see: (a) Li, Y.; Zhang, L.; Zhang, L.; Wu, Y.; Gong, Y. Eur. J. Org. Chem. 2013, 2013, 8039. (b) Xu, Q.-L.; Dai, L.-X.; You, S.-L. Org. Lett. 2012, 14, 2579. (c) Yin, Q.; You, S.-L. Org. Lett. 2012, 14, 3526. (d) Wu, Q.-F.; Liu, W.-B.; Zhuo, C.-X.; Rong, Z.-Q.; Ye, K.-Y.; You, S.-L. Angew. Chem., Int. Ed. 2011, 50, 4455. (e) Vo, N. T.; Pace, R. D. M.; O'Hara, F.; Gaunt, M. J. J. Am. Chem. Soc. 2008, 130, 404. (f) Zhuo, C.-X.; You, S.-L. Angew. Chem., Int. Ed. 2013, 52, 10056.

(7) For selected examples of dearomatization of pyrroles, see: (a) Mulcahy, J. V.; Bois, J. D. J. Am. Chem. Soc. 2008, 130, 12630. (b) Wang, D.-S.; Ye, Z.-S.; Chen, Q.-A.; Zhou, Y.-G.; Yu, C.-B.; Fan, H.-J.; Duan, Y. J. Am. Chem. Soc. 2011, 133, 8866. (c) Zhuo, C.-X.; Liu, W.-B.; Wu, Q.-F.; You, S.-L. Chem. Sci. 2012, 3, 205. (d) Wu, K.-J.; Dai, L.-X.; You, S.-L. Chem. Commun. 2013, 49, 8620. 
(8) (a) Sundberg, R. J. Indoles; Academic Press: San Diego, 1996. (b) d'Ischia, M.; Napolitano, A.; Pezzella, A. In Comprehensive Heterocyclic Chemistry III; Katritzky, A. R., Ramsden, C. A., Scriven, E. F. V., Taylor, R. J. K., Eds.; Elsevier: Oxford, 2008; Vol. 3, p 353. (c) Wang, D.-S.; Tang, J.; Zhou, Y.-G.; Chen, M.-W.; Yu, C.-B.; Duan, Y.; Jiang, G.-F. Chem. Sci. 2011, 2, 803. (d) Wang, D.-S.; Chen, Q.-A.; Li, W.; Yu, C.-B.; Zhou, Y.-G.; Zhang, X. J. Am. Chem. Soc. 2010, 132, 8909.

(9) For selected examples on alkylative dearomatization, see: (a) Chen, J.; Cook, M. J. Org. Lett. 2013, 15, 1088. (b) Zhang, X.; Liu, W.-B.; Wu, Q.-F.; You, S.-L. Org. Lett. 2013, 15, 3746. (c) Zhang, X.; Yang, Z.-P.; Liu, C.; You, S.-L. Chem. Sci. 2013, 4, 3239. (d) Zhu, S.; MacMillan, D. W. C. J. Am. Chem. Soc. 2012, 134, 10815. (e) Wu, Q.-F.; Zheng, C.; You, S.-L. Angew. Chem., Int. Ed. 2012, 51, 1680. (f) Wu, Q.-F.; He, H.; Liu, W.-B.; You, S.-L. J. Am. Chem. Soc. 2010, $132,11418$.

(10) For selected examples, see: (a) Sunazuka, T.; Hirose, T.; Shirahata, T.; Harigaya, Y.; Hayashi, M.; Komiyama, K.; Ōmura, S.; Smith, A. B. J. Am. Chem. Soc. 2000, 122, 2122. (b) Liang, J.-L.; Yuan, S.-X.; Chan, P. W. H.; Che, C.-M. Tetrahedron Lett. 2003, 44, 5917.

(11) Gioia, C.; Hauville, A.; Bernardi, L.; Fini, F.; Ricci, A. Angew. Chem., Int. Ed. 2008, 47, 9236.

(12) For selected examples, see: (a) Cai, Q.; Zheng, C.; Zhang, J.-W.; You, S.-L. Angew. Chem., Int. Ed. 2011, 50, 8665. (b) Heureux, N.; Wouters, J.; Markó, L. E. Org. Lett. 2005, 7, 5245. (c) Zhang, Z.; Antilla, J. C. Angew. Chem., Int. Ed. 2012, 51, 11778. (d) Cai, Q.; Liu, C.; Liang, X.-W.; You, S.-L. Org. Lett. 2012, 14, 4588. (e) Cai, Q.; You, S.-L. Org. Lett. 2012, 14, 3040. (f) Liu, C.; Zhang, W.; Dai, L.-X.; You, S.-L. Org. Lett. 2012, 14, 4525.

(13) For selected examples, see: (a) Austin, J. F.; Kim, S.-G.; Sinz, C. J.; Xiao, W.-J.; MacMillan, D. W. C. Proc. Natl. Acad. Sci. U. S. A. 2004, 101, 5482. (b) Kimura, M.; Futamata, M.; Mukai, R.; Tamaru, Y. J. Am. Chem. Soc. 2005, 127, 4592. (c) Kagawa, N.; Malerich, J. P.; Rawal, V. H. Org. Lett. 2008, 10, 2381. (d) Wu, K.-J.; Dai, L.-X.; You, S.-L. Org. Lett. 2012, 14, 3772. (e) Xiong, H.; Xu, H.; Liao, S.; Xie, Z.; Tang, Y. J. Am. Chem. Soc. 2013, 135, 7851. (f) Spangler, J. E.; Davies, H. M. L. J. Am. Chem. Soc. 2013, 135, 6802. (g) Zhang, H.; Hong, L.; Kang, H.; Wang, R. J. Am. Chem. Soc. 2013, 135, 14098.

(14) (a) Wessjohann, L. A.; Brandt, W.; Thiemann, T. Chem. Rev. 2003, 103, 1625. (b) Charette, A. B.; Lebel, H. J. Am. Chem. Soc. 1996, 118, 10327. (c) Barrett, A. G. M.; Kasdorf, K. J. Am. Chem. Soc. 1996, 118,11030 .

(15) For some reviews, see: (a) Wong, H. N. C.; Hon, M. Y.; Tse, C. W.; Yip, Y. C.; Tanko, J.; Hudlicky, T. Chem. Rev. 1989, 89, 165. (b) Kulinkovich, O. G. Chem. Rev. 2003, 103, 2597. (c) Brackmann, F.; de Meijere, A. Chem. Rev. 2007, 107, 4493.

(16) For some reviews, see: (a) Maas, G. Chem. Soc. Rev. 2004, 33, 183. (b) Lebel, H.; Marcoux, J. F.; Molinaro, C.; Charette, A. B. Chem. Rev. 2003, 103, 977. (c) Doyle, M. P.; Forbes, D. C. Chem. Rev. 1998, 98, 911. (d) Hoveyda, A. H.; Evans, D. A.; Fu, G. C. Chem. Rev. 1993, 93, 1307.

(17) For recent examples, see: (a) Liao, W.-W.; Li, K.; Tang, Y. J. Am. Chem. Soc. 2003, 125, 13030. (b) Ma, S.; Jiao, N.; Yang, Q.; Zheng, Z. J. Org. Chem. 2004, 69, 6463. (c) Okamoto, N.; Sasaki, M.; Kawahata, M.; Yamaguchi, K.; Takeda, K. Org. Lett. 2006, 8, 1889. (d) Li, J.; Liao, S.-H.; Xiong, H.; Zhou, Y.-Y.; Sun, X.-L.; Zhang, Y.; Zhou, X.-G.; Tang, Y. Angew. Chem., Int. Ed. 2012, 51, 8838.

(18) For reviews, see: (a) Palmieri, A.; Petrini, M.; Shaikh, R. R. Org. Biomol. Chem. 2010, 8, 1259. (b) Petrini, M. Chem. Rev. 2005, 105, 3949. (c) Nájera, C.; Yus, M. Tetrahedron 1999, 55, 10547.

(19) For recent examples, see: (a) Johnson, J. S. Angew. Chem., Int. Ed. 2004, 43, 1326. (b) Li, Y.; Shi, F.-Q.; He, Q.-L.; You, S.-L. Org. Lett. 2009, 11, 3182. (c) Jing, L.; Wei, J.; Zhou, L.; Huang, Z.; Li, Z.; Wu, D.; Xiang, H.; Zhou, X. Chem.-Eur. J. 2010, 16, 10955. (d) Martinelli, F.; Palmieri, A.; Petrini, M. Chem.-Eur. J. 2011, 17, 7183. (e) Cao, L.-L.; Ye, Z.-S.; Jiang, G.-F.; Zhou, Y.-G. Adv. Synth. Catal. 2011, 353, 3352. (f) Chen, M.-W.; Cao, L.-L.; Ye, Z.-S.; Jiang, G.-F.; Zhou, Y.-G. Chem. Commun. 2013, 49, 1660. (g) Palmieri, A.; Petrini, M. J. Org. Chem. 2007, 72, 1863. (h) Ballini, R.; Palmieri, A.;
Petrini, M.; Shaikh, R. R. Adv. Synth. Catal. 2008, 350, 129. (i) Shaikh, R. R.; Mazzanti, A.; Petrini, M.; Bartoli, G.; Melchiorre, P. Angew. Chem., Int. Ed. 2008, 47, 8707. (j) Dobish, M. C.; Johnston, J. N. Org. Lett. 2010, 12, 5744. (k) Ballini, R; Gabrielli, S.; Palmieri, A.; Petrini, M. Adv. Synth. Catal. 2010, 352, 2459. (1) Zheng, B.-H.; Ding, C.-H.; Hou, X.-L.; Dai, L.-X. Org. Lett. 2010, 12, 1688. (m) Wang, J.; Zhou, S.; Lin, D.; Ding, X.; Jiang, H.; Liu, H. Chem. Commun. 2011, 47, 8355. (n) Huang, J.-Z.; Wu, X.; Gong, L.-Z. Adv. Synth. Catal. 2013, 355, 2531.

(20) (a) Li, A.-H.; Dai, L.-X.; Aggarwal, V. K. Chem. Rev. 1997, 97, 2341. (b) McGarrigle, E. M.; Myers, E. L.; Illa, O.; Shaw, M. A.; Riches, S. L.; Aggarwal, V. K. Chem. Rev. 2007, 107, 5841. (c) Sun, X.L.; Tang, Y. Acc. Chem. Res. 2008, 41, 937. (d) Aggarwal, V. K.; Hynd, G.; Picoul, W.; Vasse, J.-L. J. Am. Chem. Soc. 2002, 124, 9964.

(21) For early examples on the synthesis of unsubstituted spirocyclopropane indolenine, see: (a) Arumugam, S.; Verkade, J. G. J. Org. Chem. 1997, 62, 4827. (b) Liu, X.; Verkade, J. G. J. Org. Chem. 1999, 64, 4840 .

(22) CCDC 970864, 970865 and 970863 separately contains the supplementary crystallographic data of $3 a, 3 p$, and $3 \mathbf{p}^{\prime}$. These can be obtained free of charge from The Cambridge Crystallographic Data Centre via www.ccdc.cam.ac.uk/data_request/cif.

(23) For selected chiral sulfonium salts examples, see: (a) Illa, O.; Arshad, M.; Ros, A.; McGarrigle, E. M.; Aggarwal, V. K. J. Am. Chem. Soc. 2010, 132, 1828. (b) Deng, X.-M.; Cai, P.; Ye, S.; Sun, X.-L.; Liao, W.-W.; Li, K.; Tang, Y.; Wu, Y.-D; Dai, L.-X. J. Am. Chem. Soc. 2006, 128, 9730. (c) Zhou, Y.-G.; Hou, X.-L.; Dai, L.-X.; Xia, L.-J.; Tang, M.H. J. Chem. Soc., Perkin Trans. 1 1999, 77.

(24) CCDC 970862 contains the supplementary crystallographic data for this paper. These can be obtained free of charge from The Cambridge Crystallographic Data Centre via www.ccdc.cam.ac.uk/ data_request/cif. 